\title{
Home Loans in DHFL Corporation Ltd Company in Chennai
}

\author{
R Ramamoorthy, Poovarasan, Prasath Alias Surendhar
}

\begin{abstract}
The reportcontains the hierarchical investigation done at DHFL. Thereport title is"A STUDY ON HOME LOANS". The report gives an outline of the Home credit Sector.Awareness ofcustomers about various kinds of items and administrations offered by dhfl. This examination was led to discover the consumer loyalty with respect to dhfl.The philosophy embraced for the investigation was through an organized survey. The information gathered from the contrastingly broke down altogether and introduced as diagrams and tables. DHFL must promote consistently and make brand an incentive for its items and administrations. The greater part of its rivals like ICICI, HDFC and LIC use TV commercials to advance their items. [1],[3],[5]
\end{abstract}

\section{Keywords : Home loan,DHFL,work}

\section{INTRODUCTION}

Home is the most significant human need, next just to sustenance, garments and safe house. Home is a significant feature of monetary improvement. It is a fundamental need of a human Being. It is where everybody can unwind in the wake of returning home from day's tiring work. It is where everybody can offer time to his/her family and spend delightful minutes with relatives. It is a crucial interest for living and one of the keys to harmony what's more, satisfaction. Each animal longs for a home. The first and the best preparing ground for individuals' advancement of their fluctuated offices is home. It comprises a very critical piece of the social and physical condition where the people develop and develop as productive members of society. It likewise assumes a significant job in making work, looking after wellbeing, social strength and protecting respectable human life. Home satisfies numerous prerequisites. Home gives stylish fulfillment, enthusiastic fulfillment, psychological wellness, physical wellbeing, solace and security. It gives cover from the risks of flame and caprices of climate, it makes conditions advancing great wellbeing for example, unadulterated water and transfer of a wide range of waste, it gives sufficient space of protection, it makes/gives harmonious surroundings in which an individual can work and unwind. Lodging is an exceptionally perplexing item. It is a cumbersome, strong and perpetual item. It has fixed area,

Revised Manuscript Received on July 22, 2019.

Ramamoorthy R, Department of MBA, Bharath Institute of Higher Education and Research, Tamilnadu, India. Email: ramamoorthy0071@gmail.com

Poovarasan, Department of MBA, Bharath Institute of Higher Education and Research, Tamilnadu, India. Email: poovarasanmba @gmail.com

Prasath Alias Surendhar, Department of Biomedical Engineering, Bharath Institute of Higher Education and Research, Tamilnadu, India. Email: mail.surendhar@gmail.com being utilized distinctly in where it is fabricated. When fabricated, it will in general stay in presence for a long time. The houses extend from single - family houses to numerous different kinds. Be that as it may, lodging is in excess of a mind boggling item. It is both an financial and social procedure. It assumes a huge job in the economy. Lodging has profoundly noteworthy social ramifications since it gives the safe house to our essential unit the family. Pretty much every individual is influenced in his everyday living by the sort of house in which he lives. In well known creative mind a house is a structure with a kitchen, a restroom, room also, a parlor. It will be fabricated sturdily enough to withstand normal components, and it will have a location on the register of the mail station. A portion of the lodging in India's biggest [31],[33],[32] urban communities fit this kind of portrayal. Be that as it may, numerous city occupants don't live in such places. A few of the most unfortunate are housed in space on an asphalt, close to their low-paid work. Others will have a rooftop, dividers and an entryway, set in a no man's land along stream banks, near railroad lines, or in wherever where there is a fix of land available. We have a versatile perspective on lodging. It is a sanctuary, it is identified with capital markets, it is inside state jobs, it has association with urbanization being developed as a entire, and it is to some degree attached to basic condition in the economy. It very well may be seen as utilization yet to consider it to be creation yields bits of knowledge into its basic and sex disparities and its profitability in the public arena. [2 ],[ 4],[6]

\section{OBJECTIVES}

A. Primary Objective

The objectives of the A study on analysis of home loan at Dewan finance housing corporation Ltd.

B. Secondary Objectives

- To assessing and looking at the Home Loan arrangement of money Private Ltd organization.

- To assessing and looking at the Home Loan dispensing of account Private Ltd organization.

- To knowing client's frame of mind or reaction on the home credits plans

- To realizing clients' fulfillment level while managing the organization

- To recommending systems to build consumer 
loyalty, comprehend the purposes behind default.

- To realize different rates accessible while giving home advance.

- To investigate Indian home advance market and its developing patterns

\section{RESEARCH DESIGN}

An exploration configuration is the determination of techniques and systems for obtaining the data required. It is the general operational example or system of the undertaking that stipulates what data is to be gathered from which source by what methods. Research configuration indicates the depiction of the exploration structure. The point was to gather important data, which satisfy our necessity and can be examined at a later phase of concentrate with no issue. [7],[9],[11]

This was to be done in least consumptions and least endeavors and in a set timeframe. For instance The Home Loan Scheme Offered By ICICI Bank And HDFC Bank and DHFL partnership Ltd.This helped us in having enough arrangement for security against predisposition and amplifies unwavering quality. Engaging investigation, as its name infers, is intended to depict something - for instance, the qualities of the clients of a given item, how much item use changes with salary, age, or different attributes. [8],[10],[12]

\section{A. METHOD OF DATA COLLECTION}

This is the investigation to pass judgment on the practices of the clients looking for house credit in the market of Guindy. To make the investigation achievable and concrete due thought is given to the age, pay level and occupation andvarious factor influencing the house credit taking choice of client. [13], [15], [ 17]

Table: 1 TABLE SHOWS AMOUNT OF HOME LOAN APPLIED

\begin{tabular}{|l|l|l|}
\hline AMOUNT (IN LAKHS) & RESPONDENTS & PERCENTAGE \\
\hline 1 to 5 lakhs & 32 & $32 \%$ \\
\hline 5 to 10 lakhs & 33 & $33 \%$ \\
\hline 10 to 20 lakhs & 27 & $27 \%$ \\
\hline Above 20 lakhs & 08 & $8 \%$ \\
\hline Total & $\mathbf{1 0 0}$ & $\mathbf{1 0 0}$ \\
\hline
\end{tabular}

Table-3 DURATION TAKEN BY YOUR COMPANY TO SANCTION A HOME LOAN

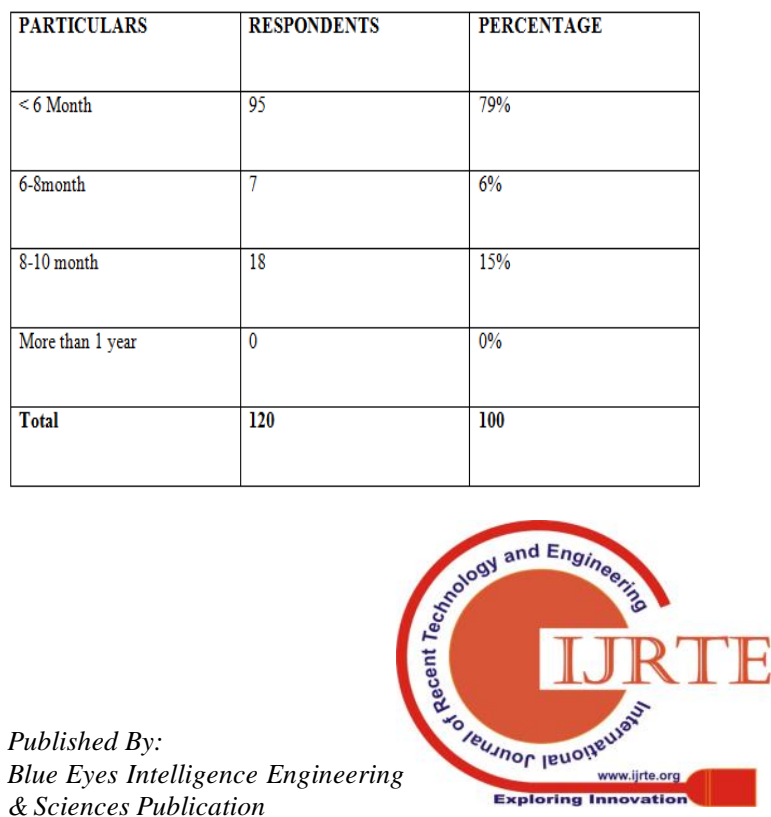




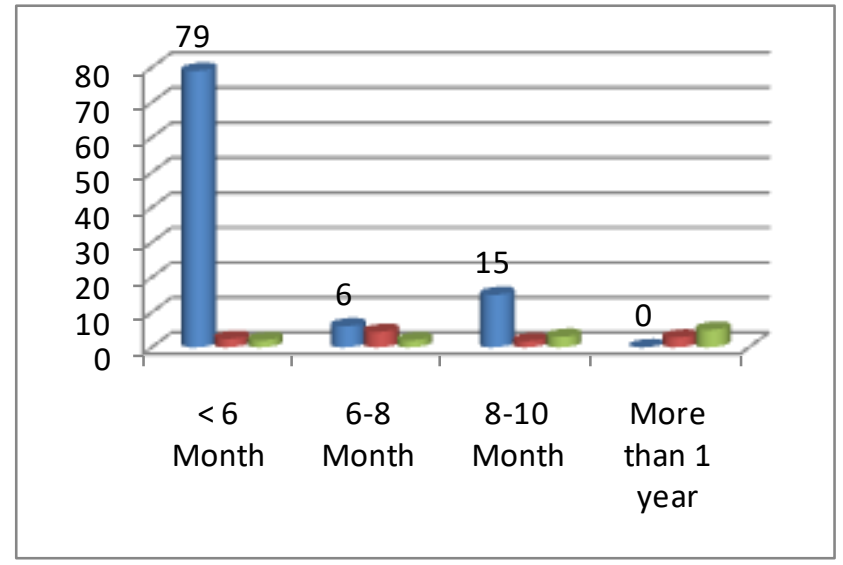

Fig:3 DURATION TAKEN BY YOUR COMPANY TO SANCTION A HOME LOAN

Table-4 AMOUNT OF LOAN SANCTIONED

\begin{tabular}{|l|l|l|}
\hline PARTICULARS & RESPONDENTS & PERCENTAGE \\
\hline $5-10$ lakhs & 32 & $32.0 \%$ \\
\hline $11-15$ lakhs & 33 & $33.0 \%$ \\
\hline $15-201$ lakhs & & \\
\hline$>20$ lakhs & 27 & $27.0 \%$ \\
\hline Total & 8 & $08.0 \%$ \\
\hline
\end{tabular}

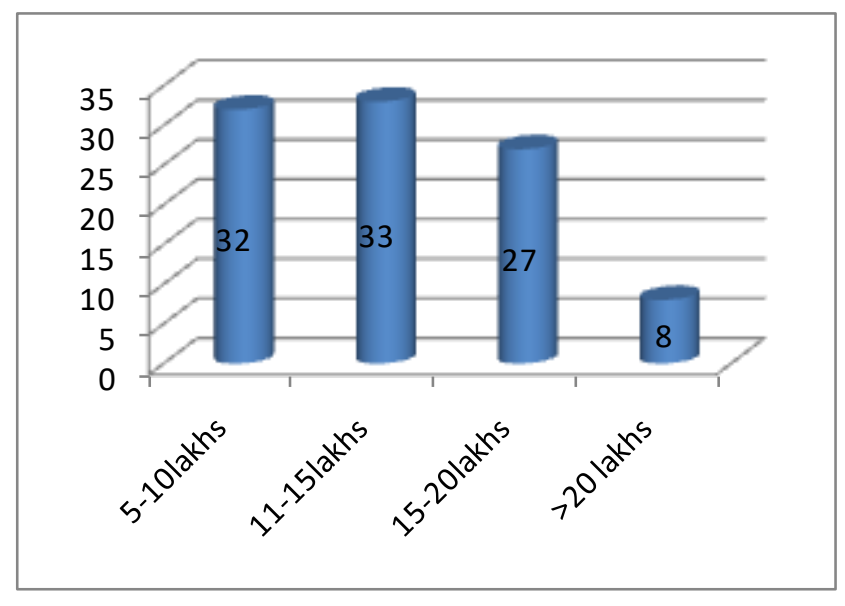

Fig -4.THE AMOUNT OF HOME LOAN SANCTIONED

Table:5

\begin{tabular}{|l|l|l|l|l|}
\hline $\mathbf{0}$ & $\begin{array}{l}\text { E=RT } \\
\text { (*) CT }\end{array}$ & $(0-\mathrm{E})$ & $(0-\mathbf{E})^{2}$ & $(0-\mathrm{E})^{2} / \mathbf{E}$ \\
\hline 17 & GT & & & \\
\hline 35 & 18.2 & -1.2 & 1.44 & 0.0791 \\
\hline 25 & 33.8 & 1.2 & 1.44 & 0.0426 \\
\hline 43 & 23.8 & 1.2 & 1.44 & 0.0605 \\
\hline & 44.2 & -1.2 & 1.44 & 0.0325 \\
\hline
\end{tabular}

$$
x^{2}=\sum \frac{\left(O_{i}-E_{i}\right)^{2}}{E_{i}}
$$

$\mathrm{X}^{2}$ col $=\mathbf{0 . 2 1 4 7}$

Table-6 WHAT IS YOUR OPINION ABOUT HOME LOAN FACILITIES

\begin{tabular}{|l|l|l|}
\hline PARTICULAR & RESPONDENTS & PERCENTAGE \\
\hline Highly satisfied & 23 & 19 \\
\hline Highly dissatisfied & 26 & 21 \\
\hline Dissatisfied & 0 & 0 \\
\hline Satisfied & & \\
\hline Netural & 46 & 38 \\
\hline Total & 25 & 20 \\
\hline & & 100 \\
\hline
\end{tabular}

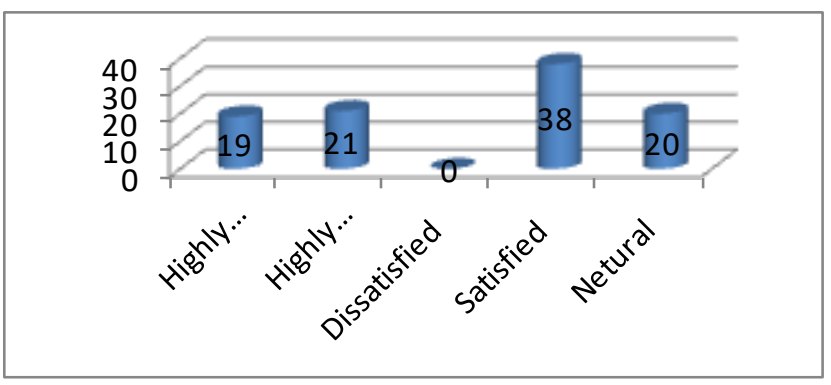

Fig:6 WHAT IS YOUR OPINION ABOUT HOME

\section{LOAN FACILITIES}

\section{RESULTS}

- Majority of the client are happy with dfhl.

- The $60 \%$ of the respondent is exceptionally happy with the home credit offices.

- The $36 \%$ of the respondent state is administration given, and $38 \%$ of the respondent is have financing cost.

- About $48 \%$ of the respondents were moderately aged 31 to 40 years old. 
- The $33 \%$ of the respondents for the home credit connected 5-10 lakhs.

- The half of the respondents were from business class, while $39 \%$ were from administration class.

- The greatest number of respondents (32\%) had yearly pay of 2.4 to 3.6 lakhs and $19 \%$ had salary more than 3.6 lakhs.

- The $46 \%$ of the respondents is exceptionally happy with the loan fee.

- A lion's share of 55 respondents were Graduate.

- Most of the respondents profited of the data about the home advance from other sources"like C.A/credit specialist/friends, etc.

- People get learning about home advance from TV, web or families and companions.

- The nature of administration and least pace of intrigue are the significant criteria which are seen by the individuals before bringing home advances.

- The $79 \%$ of the respondent for the home advance endorsed $<6$ month.

- The $33 \%$ of the respondent got data about home advance plan from paper.

- The $48 \%$ of the respondent have delivered land paper.

- The half of respondents says over 20 years of reimbursement of credit.

- The $40 \%$ of the respondents says living arrangement evidence requested for home credits.

\section{V.DISCUSSION}

- More stress should give on the ad and limited time exercises.

- The dfhl should attempt a few endeavors to improving great association with client.

- The dfhl should enchance their administrations as indicated by the requirements of the client. [20],[ 22], [24]

- The dfhl makes it techniques less tedious.

- The dfhl endeavor to mindful the clients about their everything the additional administrations.

- To pull in more customers,dfhl should make procedure of credit reimbursement simple.
- It likewise recommended that they need to give home advance offices to all classes of occupation individuals, for example, government area worker and so on. [25],[27],[29]

- It is proposed that dfhl needs to decrease the financing cost brought about for home credits with the goal that individuals does not get dither to profit home advance. [26],[28],[30]

\section{CONCLUSION}

This examination features the fulfillment level of clients towards the administrations of the dfhl. Having thought about the age, sex, instructive capabilities and month to month salary of 150 respondents, a last information has been arrived and call attention to that there is a medium degree of fulfillment on the clients side. [14],[ 16], [18]

With variables like representative behaviour,dfhl administrations and dfhl execution influencing the degree of client satisfaction.Thedfhl needs to incite client cordial plans/portfolios as an initativego. These would there by go far to enchance the degree of clients fulfillment along these lines amending clients stresses and reduce the quantity of clients too. Maybe this would prompt a prospering economy, since consumer loyalty is the rotate of a fruitful dfhl structure. [19],[21],[23]

\section{REFERENCES}

1. G BharthVajan R., Ramachandran S.,Psychographic dimensions of training,2016,International Journal of Pharmacy and Technology,V-8,I-4,P-23727-23729

2. Balakrishnan P., Bharthvajan R.,A study on human resource planning in hospitals in Chennai City,2014,International Journal of Applied Engineering Research,V-9,I-22,P-7503-7507

3. Priyadarsini P., Bharthvajan R.,Role of emotional intelligence training programme in reducing the stress of the nurses,2014,International Journal of Applied Engineering Research,V-9,I-22,P-7411-7421

4. Kerinab Beenu G., Bharthvajan R.,Empirical analysis on the cosmetic buying behavior of young women in South India,2014,International Journal of Applied Engineering Research,V-9,I-22,P-7361-7366

5. Balakrishnan P., Bharthvajan R.,Whistling in the wind,2014,International Journal of Applied Engineering Research,V-9,I-22,P-7586-7593

6. Krishnan B., Peter M.,Health hazards of Indian Bpo employee-an alarming issue,2014,International Journal of Applied Engineering Research,V-9,I-22,P-7336-7341

7. Kerinab Beenu G.H., Peter M.,Role of insurance in economic development,2014,International Journal of Applied Engineering Research,V-9,I-22,P-7532-7539

8. Balakrishnan P., Peter M., Priyadarsini P.,Efficiency of safety measures for wellbeing of employees in manufacturing industry,2014,International Journal of Applied Engineering Research,V-9,I-22,P-7376-7382

9. Anbarasi M., Praveen Kumar S.,Online sales promotions of herbal products and its effectiveness towards tanisha.com,2019,Indian Journal of Public Health Research and Development,V-10,I-1,P-195-200

10. Anbarasi M., Praveen Kumar S.,Various online marketing and promotions strategies to improve the validation towards the organic products in the pharmaceutical sectors,2019,Indian Journal of Public Health Research and Development,V-10,I-1,P-263-269

11. Loganathan R., Praveen Kumar S.,Grievance handling a key factor for solving issues of employees in an organization,2014,International Journal of Applied Engineering Research,V-9,I-22,P-7483-7491

12. Loganathan R., Praveen Kumar S.,Study on preference of private label brands in super and Hypermarkets,2014,International Journal of Applied Engineering

Research,V-9,I-22,P-7327-7335 


\section{AUTHORS PROFILE}

13. Smitha M., Praveen Kumar S.,Understanding stress and its managementamong the nurses in Chennai city,2014,International Journal of Applied Engineering Research,V-9,I-22,P-7560-7565

14. Kerinab Beenu G.H., Praveen Kumar S.,A study on the investment behavior of Chennai investors in mutual fund schemes,2014,International Journal of Applied Engineering Research,V-9,I-22,P-7520-7525

15. Loganathan R., Praveen Kumar S.,Retention strategies key for organizational productivity,2014,International Journal of Applied Engineering Research,V-9,I-22,P-7443-7447

16. Pavithra J., Ganesan M., Brindha G.,State wise analysis of microfinance sector in India,2016,International Journal of Pharmacy and Technology,V-8,I-4,P-23417-23432

17. Pavithra J., Ganesan M.,A comparative study on microfinance in India and abroad,2016,International Journal of Applied Business and Economic Research,V-14,I-8,P-5471-5476

18. Pavithra J., Ganesan M.,A study on awareness and impact of micro-financial schemes,2016,International Journal of Applied Business and Economic Research,V-14,I-8,P-5449-5460

19. Senthilmurugan P., Pavithra J.,Consumer preference towards organised retailing with reference to Big Bazaar,2014,International Journal of Applied Engineering Research,V-9,I-22,P-7469-7475

20. Senthilmurugan P., Pavithra J.,Implication of social media marketing in growing healthcare industry,2014,International Journal of Applied Engineering Research,V-9,I-22,P-7448-7456

21. Loganathan R., Pavithra J.,Consumer perception towards private label brand over other brands in super markets and hypermarkets,2014,International Journal of Applied Engineering Research,V-9,I-22,P-7355-7360

22. Kerinab Beenu G., Pavithra J.,Tradeâ€"off between liquidity and profitability in logistics industry,2014,International Journal of Applied Engineering Research,V-9,I-22,P-7398-7401

23. Kerinab Beenu G., Pavithra J.,A study on the prospective consumerâ $€^{\mathrm{TM}_{\mathbf{S}}}$ perception towards utility cars in Chennai city,2014,International Journal of Applied Engineering Research,V-9,I-22,P-7526-7531

24. Pavithra J., Dilli Babu P., Ambuli T.V.,A study on budgetary control at Maruti Service Masters, Chennai,2014,International Journal of Applied Business and Economic Research,V-12,I-2,P-151-161

25. Pavithra J., Dilli Babu P., Ambuli T.V.,A study on customer satisfaction of retro Garments Pvt Ltd, Chennai,2014,International Journal of Applied Business and Economic Research,V-12,I-2,P-381-391

26. Kerinab Beenu G.H., Pavithra J., Senthilmurugan P.,A study on the influence of promotional activities for TATA ARIA among consumers in Chennai,2014,International Journal of Applied Engineering Research,V-9,I-22,P-7572-7578

27. Vijayaragavan S.P.,An investigative expert that's general FBG sensors,International Journal of Mechanical Engineering and Technology,V-8,I-8,PP-1500-1505,Y-2017

28. Vijayaragavan S.P.,Equalization routing protocol for $\mathrm{Wi}-\mathrm{Fi}$ sensor strategy,International Journal of Mechanical Engineering and Technology,V-8,I-8,PP-1662-1666,Y-2017

29. Karthik B., Kiran Kumar T.V.U., Vijayaragavan P., Bharath Kumaran E.,Design of a digital PLL using 0.35 $\hat{\mathrm{I}}^{1} / 4 \mathrm{~m}$ CMOS technology,Middle East Journal of Scientific Research,V-18,I-12,PP-1803-1806,Y-2013

30. Kanniga E., Selvaramarathnam K., Sundararajan M.,Kandigital bike operating system,Middle - East Journal of Scientific Research, V

31. Jasmin M., Vigneshwaran T., Beulah Hemalatha S.,Design of power aware on chip embedded memory based FSM encoding in FPGA,International Journal of Applied Engineering Research,V-10,I-2,PP-4487-4496,Y-2015

32. Jasmin M.,Optimization techniques for low power VLSI circuits,Middle East Journal of Scientific Research,V-20,I-9,PP-1082-1087,Y-2014

33. Jasmin M., Vigneswaran T.,Fuzzy controller for error control of on - Chip communication,2017 International Conference on Algorithms, Methodology, Models and Applications in Emerging Technologies, ICAMMAET 2017,V-2017-January,I-,PP-1-5,Y-2017

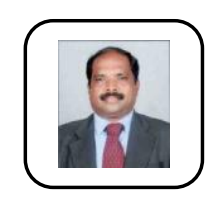

Ramamoorthy Assistant Professor ,Department of MBA, Bharath Institute of Higher Education and Research, Tamilnadu, India

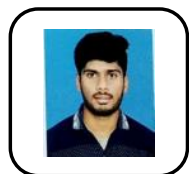

Poovarasan Student, Department of MBA, Bharath Institute of Higher Education and Research, Tamilnadu, India

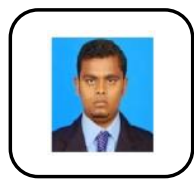

Prasath alias Surendhar Department of Biomedica engineering, Bharath Institute of Higher Education and Research, Tamilnadu, India 